\title{
E-waste: Environmental Problems and Current Management
}

\author{
G. Gaidajis*, K. Angelakoglou and D. Aktsoglou
}

Department of Production Engineering and Management, School of Engineering, Democritus University of Thrace, 67100, Xanthi, Greece.

Received 31 August 2010; Accepted 9 October 2010

\begin{abstract}
In this paper the environmental problems related with the discarded electronic appliances, known as e-waste, are reviewed. Moreover, the current and the future production of e-waste, the potential environmental problems associated with their disposal and management practices are discussed whereas the existing e-waste management schemes in Greece and other countries (Japan, Switzerland) are also quoted.
\end{abstract}

Keywords: e-waste management, environmental pollution, recycling.

\section{Introduction}

In the last years, there is an increasing acknowledgment of our impact on the environment due to our lifestyle, while the need to adopt a more sustainable approach concerning our consumption habits emerges as of particular significance. This trend regards industrial sectors affecting the consumption habits and, especially, electronic industry where the short life cycles and the rapidly developing technology have led to increased e-waste volumes. The majority of e-waste elements are led to landfills. However, their partial recyclability, due to their material composition along with the unavoidable restrictions in landfills, has led to the development of retrieval techniques for their recycling and re-use, highlighting the significance of e-waste recycling, not only from a waste management aspect but also from a valuable materials' retrieval aspect.

E-waste is often misinterpreted as related to old computers or IT equipment in general, while the synonymous term Waste Electrical and Electronic Equipment (WEEE) is also used in the international literature. Several e-waste definitions are summarized in Table 1.

Table 1. Summary of selected e-waste definitions.

\begin{tabular}{cl}
\hline Reference & \multicolumn{1}{c}{ Term-definition } \\
\hline & "Waste electrical and electronic equipment, including \\
all components, subassemblies and consumables which \\
are part of the product at the time of discarding". The \\
Directive 75/442/EEC, Article I (a), defines as "waste" \\
"any substance or object which the holder discards or \\
is required to discard in compliance with the national \\
legislative provisions".
\end{tabular}

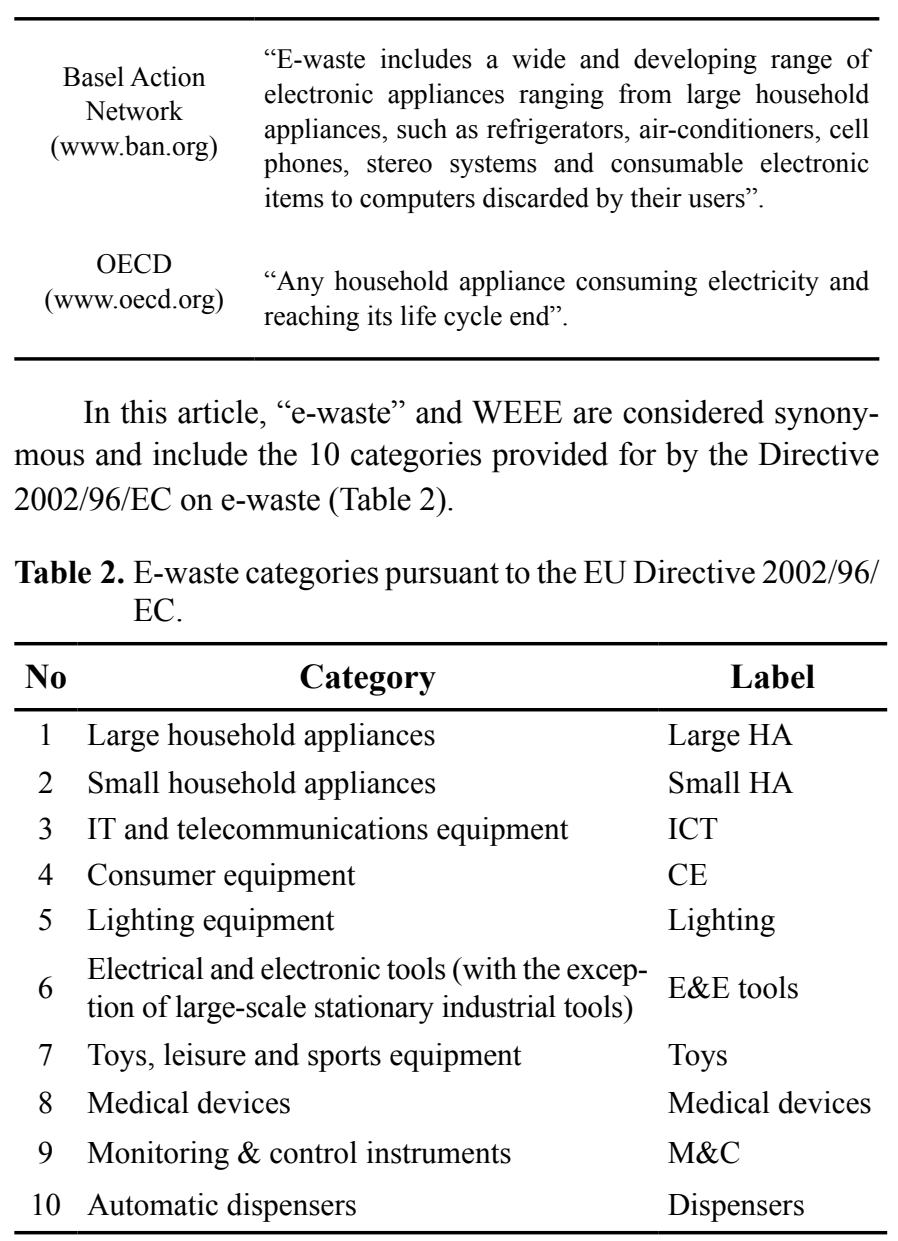


E-waste differs chemically and physically wise from urban or industrial waste. It contains both dangerous and valuable materials requiring special treatment and recycling practices to avoid adverse environmental impact and harmful impact on human health. Retrieving the valuable and base metals is possible by recycling e-waste, but the high labour cost and the strict environmental legislation have consolidated these activities' implementation mostly in Asian countries such as China and India [1] by use of obsolete methods and inadequate emphasis on the employees' protection [2]. As a result, the e-waste disposal issue has attracted the interest of politicians, non-governmental organizations, such as Greenpeace (www.greenpeace.org), Basel Action Network (www. ban.org), Silicon Valley Toxics Coalition (www.svtc.org) and the scientific community.

\section{E-waste Production}

\subsection{Current Situation}

The global e-waste production is assessed at 20-50 Mt/year [3], equal to $1-3 \%$ of the estimated global urban waste production (1636 Mt) [4, 2]. PCs, cell phones and TVs will contribute $5.5 \mathrm{Mt}$ in 2010 and will amount to $9.8 \mathrm{Mt}$ in 2015. In wealthier countries, e-waste will stand for $8 \%$ of the urban waste volume [5]. Each electronic item's participation in the annual e-waste production, E (kg/year), depends on each electronic item's mass, $\mathrm{M}(\mathrm{kg})$, its quantity (number) in the market and consumption, $\mathrm{N}$, and its average life cycle, $\mathrm{L}$ (year).

$$
\mathrm{E}=\mathrm{MN} / \mathrm{L}
$$

Electronic computers with an average 3-year life cycle [6] contribute to a greater extent to the total e-waste flow compared to refrigerators and electrical cook-stoves, having an average life cycle of 10-12 years. Certain e-waste types along with their mass and estimated life cycle are summarized in Table 3.

Particularly for the European Union, the e-waste quantities increase by $3-5 \%$ per year [9], a rate three times faster than the urban solid waste. During the 1990-1999 period the quantities produced in EU-15 were approximately 3.3-3.6 kg/resident, while estimated quantities for the 2000-2010 period vary between 3.9-4.3 $\mathrm{kg} /$ resident [5]. Using the equation (1), Swiss is estimated to produce $9 \mathrm{~kg} /$ person/year [10], the European population $14 \mathrm{~kg} /$ person/ year [11], with the total EU-15 production amounting to $5.5 \mathrm{Mt} /$ year and, in case of EU-27, 8.3-9.1 Mt/year [12]. USA produced approximately 2.6 Mt [2], while China produced 2.5 Mt in 2005 [13]. There are no available data for poorer countries, but it was assessed that India and Thailand produced 0.3 and $0.1 \mathrm{Mt}$ of e-waste in 2007 [2].

According to another calculation based on the equation (1), Tab. 3 and available data for the total number of PCs $(0.78$ billion units), cell phones (3.4 billion units), stationary phones ( 1.2 billion units), TVs (1.4 billion units), and radios (2.5 billion units), the total production amounts to $11.7 \mathrm{Mt} /$ year [7]. Moreover, considering the constantly increasing production of e-waste and the fact that the relatively large-mass electrical appliances (refrigerators, air-conditioners etc.) are not included in the aforementioned calculation, it is estimated that the total e-waste quantities will be rather larger. If the global increase of GDP by approximately $20 \%$ in the last 6 years is also considered, then the aforementioned estimate of 20-50 Mt/year [3] is justified.

Table 3. E-waste types and their estimated life cycle.

\begin{tabular}{|c|c|c|}
\hline Item & $\begin{array}{c}\text { Mass of } \\
\text { Item (kg) }\end{array}$ & $\begin{array}{l}\text { Estimated } \\
\text { life (years) }\end{array}$ \\
\hline Personal Computer $(\mathrm{PC})^{\mathrm{a}}$ & 25 & 3 \\
\hline Fax machine $e^{b}$ & 3 & 5 \\
\hline High-fidelity system ${ }^{c}$ & 10 & 10 \\
\hline Cell phone ${ }^{\mathrm{c}}$ & 0.1 & 2 \\
\hline Electronic games ${ }^{\mathrm{c}}$ & 3 & 5 \\
\hline Photocopier ${ }^{\mathrm{b}}$ & 60 & 8 \\
\hline Radio $^{c}$ & 2 & 10 \\
\hline Television $(\mathrm{TV})^{\mathrm{d}}$ & 30 & 5 \\
\hline Video recorder/DVD Player ${ }^{\mathrm{c}}$ & 5 & 5 \\
\hline Air-conditioner ${ }^{\mathrm{b}}$ & 55 & 12 \\
\hline Dish washer ${ }^{\mathrm{c}}$ & 50 & 10 \\
\hline Electric cooker & 60 & 10 \\
\hline Food mixer ${ }^{c}$ & 1 & 5 \\
\hline Freezer $^{\mathrm{c}}$ & 35 & 10 \\
\hline Hair-dryer ${ }^{c}$ & 1 & 10 \\
\hline Iron $^{\mathrm{c}}$ & 1 & 10 \\
\hline Kettle & 1 & 3 \\
\hline Microwave $^{\mathrm{c}}$ & 15 & 7 \\
\hline Refrigerator $^{\mathrm{c}}$ & 35 & 10 \\
\hline Telephone ${ }^{\mathrm{c}}$ & 1 & 5 \\
\hline Toaster ${ }^{\mathrm{c}}$ & 1 & 5 \\
\hline Tumble Dryer ${ }^{c}$ & 35 & 10 \\
\hline Vacuum cleaner ${ }^{\mathrm{c}}$ & 10 & 10 \\
\hline Washing machine ${ }^{\mathrm{c}}$ & 65 & 8 \\
\hline
\end{tabular}

\section{${ }^{\mathrm{a}}[6],{ }^{\mathrm{b}}[7],{ }^{\mathrm{c}}[2],{ }^{\mathrm{d}}[8]$.}

\subsection{Future trends}

The global e-waste production is estimated to increase due to the economic growth and the available technologies since the increased GDP leads to increased purchasing of electronic goods and

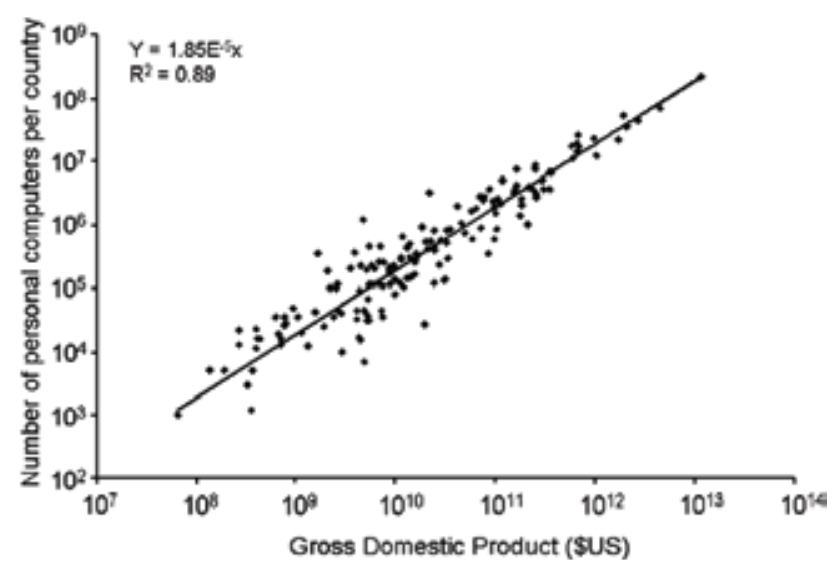

Figure 1. Number of PCs per country related to the country's GDP for 161 countries (Source: [7]). 
eventually to increased e-waste production. For example, the total number of PCs for each country is related to the country's GDP (see Figure 1).

The increasing economic growth is anticipated to reflect higher e-waste production as it is shown in Fig.1. On the contrary, it is anticipated that specific changes in the technology and the consumption habits are expected to decrease the global e-waste production, since consumers may favor more portable PC solutions having 1-3 kg average weight compared to the stationary computer weighing $25 \mathrm{~kg}$, or the stationary computers is expected to be equipped with LCD (Liquid Crystal Display) screens instead of the older CRTs (Cathode Ray Tube).

\section{Environmental Impacts}

\subsection{Potential environmental problems related to e-waste}

In Figure 2, all possible e-waste routes and flows and their potential environmental impact are summarized. The chemical composition of e-wastes depends on the type and the age of the electronic object discarded. It is usually predominated by several metal alloys, especially $\mathrm{Cu}, \mathrm{Al}$ and $\mathrm{Fe}$ attached to, covered with or mixed with several plastics or ceramics. The different substances-elements-pollutants related to e-waste are presented in Table 4. Some of them, such as heavy metals, are used in the production of electronic items, while others, such as Polycyclic Aromatic Hydrocarbons (PAHs) are produced by e-waste burning at low temperature. Burning the isolating plastic cover of cables in open barrels produces 100 times more dioxins than domestic waste burning [14].

Considering that the annual e-waste production approximates 20Mt, the total quantities of the several pollutants contained in the e-waste flow result, to a great extent, in landfills or recycling centres affecting the environment and/or public health. Therefore, despite significant recycling, e-waste is liable for $5000 \mathrm{t} \mathrm{Cu}$ annually released to the environment [17]. PBDEs (Polybrominated diphenyl ethers) are combustion retardants that finally result in the environment and, given that they are lipophilic compounds, are bioaccumulated in living organisms [18], while the refrigerators and air-conditioners discarded contain CFCs (Chlorofluorocarbons) that will eventually destroy the ozone layer when, in the

Table 4. Potential environmental pollutants produced from e-waste management procedures.

\begin{tabular}{|c|c|c|c|}
\hline Substance & $\begin{array}{l}\text { Occurrence in } \\
\text { e-waste }\end{array}$ & $\begin{array}{l}\text { Typical concentration } \\
\text { in e-waste }(\mathrm{mg} / \mathrm{kg})^{\mathrm{a}}\end{array}$ & $\begin{array}{l}\text { Global emis- } \\
\text { sions (tons) }\end{array}$ \\
\hline \multicolumn{4}{|c|}{ Halogenated compounds: } \\
\hline PCB & Condensers, Transformers & 14 & 280 \\
\hline TBBA, PBB, PBDE & Fire retardants for plastics (thermoplastic components, cable insulation) & & \\
\hline $\mathrm{CFC}$ & Cooling unit, Insulation foam & & \\
\hline PVC & Cable insulation & & \\
\hline \multicolumn{4}{|c|}{ Heavy metals and other metals: } \\
\hline Antimony & Fire retardant, plastics & 1,700 & 34,000 \\
\hline Arsenic (As) & Small quantities in the form of gallium arsenide within light emitting diodes & & \\
\hline Barium $(\mathrm{Ba})$ & Getters in CRT & & \\
\hline Beryllium (Be) & Power supply boxes which contain silicon controlled rectifiers and x-ray lenses & & \\
\hline Cadmium (Cd) & $\begin{array}{l}\text { Rechargeable NiCd-batteries, fluorescent layer (CRT screens), printer inks and toners, } \\
\text { photocopying-machines (printer drums) }\end{array}$ & 180 & 3,600 \\
\hline Chromium $(\mathrm{Cr})$ & Data tapes, floppy-disks & 9,900 & 198,000 \\
\hline Copper $(\mathrm{Cu})$ & Cabling & 41,000 & 820,000 \\
\hline Lead $(\mathrm{Pb})$ & CRT screens, batteries, printed wiring boards & 2,900 & 58,000 \\
\hline Lithium (Li) & Li-batteries & & \\
\hline Mercury (Hg) & $\begin{array}{l}\text { Fluorescent lamps that provide backlighting in LCDs, in some alkaline batteries and mer- } \\
\text { cury wetted switches }\end{array}$ & 0.68 & 13.6 \\
\hline Nickel (Ni) & Rechargeable NiCd-batteries or NiMH-batteries, electron gun in CRT & 10,300 & 206,000 \\
\hline Rare Earth elements & Fluorescent layer (CRT-screen) & & \\
\hline Selenium (Se) & Older photocopying-machines (photo drums) & & \\
\hline $\operatorname{Tin}(\mathrm{Sn})$ & Solder metal glue, LCD & 2,400 & 48,000 \\
\hline Zinc sulphide & Interior of CRT screens, mixed with rare earth metals & 5,100 & 102,000 \\
\hline \multicolumn{4}{|l|}{ Others: } \\
\hline Toner Dust & Toner cartridges for laser printers / copiers & & \\
\hline $\begin{array}{l}\text { Radio-active sub- } \\
\text { stances }\end{array}$ & Medical equipment, fire detectors, active sensing element in smoke detectors & & \\
\hline
\end{tabular}

Adapted from $[15,7] .{ }^{\mathrm{a}}[16]^{\mathrm{b}}[7]$ 


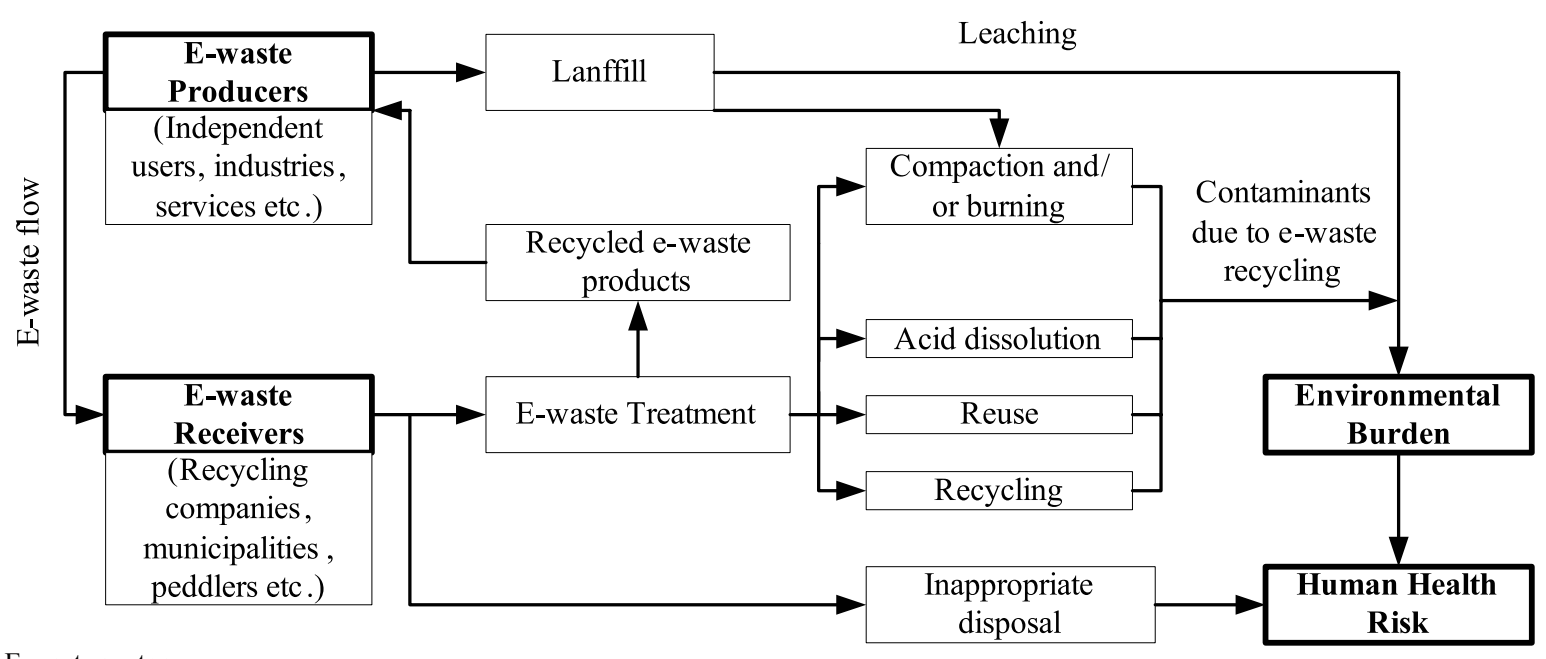

Figure 2. E-waste routes.

future, CFCs escape from the e-waste dumping site [19].

The aforementioned problems grow bigger considering the fact that the majority of e-waste are not recycled, because several electronic and electrical items are discarded along with household waste and are subject to no further treatment [20]. Approximately $80 \%$ of the quantity collected for recycling is exported to countries such as China, India, Pakistan, Vietnam, Philippines, Malaysia, Nigeria, Ghana etc. [21]. This results in their treatment in very loose environmental frameworks having increased impact on the environment and the employees in the specific operations. Nongovernmental organizations, such as Greenpeace, report this «secret flow» of e-waste [2].

\subsection{Environmental pollution caused by e-waste disposal and recycling}

The majority of e-waste is led to (sanitary) landfill sites. The implementation of the appropriate, in this case, TCLP (Toxicity Characteristic Leaching Procedure) test has showed that e-waste discarded at urban waste dumping sites do not produce leachates with heavy metals concentrations exceeding the environmental limits [22]. Nevertheless, this chemical cocktail generated as leachate following the TCLP test from several electronic items was toxic for aquatic organisms [23]. Moreover, the usual management practice of e-waste compression before or during discarding in landfills may increase the leachate volumes due to the disturbance of the several electronic circuit parts and, for that reason, it is proposed to perform cement solidification on e-waste that increases $\mathrm{pH}$ and decreases the aqueous solutions' flow in the waste discarded [24]. Burning before discard at landfill sites increases heavy metals mobility contained in circuits covered with a plastic grid and, for that reason, while not being bioavailable following wash-out, they are released to the atmosphere during burning.

On the other hand, e-waste recycling includes disassembling and destroying the individual parts to retrieve several materials. Through recycling, $95 \%$ of a computer's useful materials and $45 \%$ of a cathode ray tube's materials can be retrieved [20]. Recycling methods have minimum environmental impact when combined with the application of appropriate technology, such as in Japan [25], while, on the contrary, when using the practices followed in developing countries (e.g. child labour, e-waste burning and emission of several pollutants to the air, leachate seepage in underground and surface aquifers etc.) the final environmental benefit-impact balance is not always positive. It must be also stressed out that any environmental benefit from recycling vanishes when the waste to be recycled is transported to great distance due to the adverse environmental impact of the energy consumed for its transportation [26], while, recycling, in any case, has smaller ecological footprint than e-waste dumping and burning [9].

\section{E-waste management - Current situation}

\subsection{Greece}

The average annual e-waste production in Greece for the period 2003-2006 came up to approximately $170 \mathrm{Kt}$, representing $3.8 \%$ of the total amount of domestic solid waste [27]. $90 \%$ of e-waste for the same period had been mixed with other urban solid waste or had been recycled with other materials (e.g. metal waste), with no prior process (a management practice mentioned as "grey recycling"). In order to deal both with the developing problem of "grey recycling" and the increasing amounts of e-waste, the operation of an authorized alternative e-waste management system started in 2004, having as main responsibilities the collection, transposition and process in special facilities. The system collected approximately 0.1 kilotons $(\mathrm{Kt})$ in 2005 , first year of operation, 31.5 $\mathrm{Kt}$ in $2007,47 \mathrm{Kt}$ in 2008 and $25 \mathrm{Kt}$ in the first five months of 2009 , overbalancing the national goal, as defined by the European and Greek legislation. These goals include the separate collection of at least $4 \mathrm{~kg} / \mathrm{resident} / \mathrm{year}$ of e-waste of domestic origin, that is $44 \mathrm{Kt} /$ year for Greece in total. Nevertheless, even today the management of discarded electronic appliances is not taken place in a controlled way, resulting to uncontrolled collection by street vendors and to their promotion to metal and alloy recovery units (See Figure 3).

\subsection{European Union}

In the European Union, e-waste has been targeted regarding the 


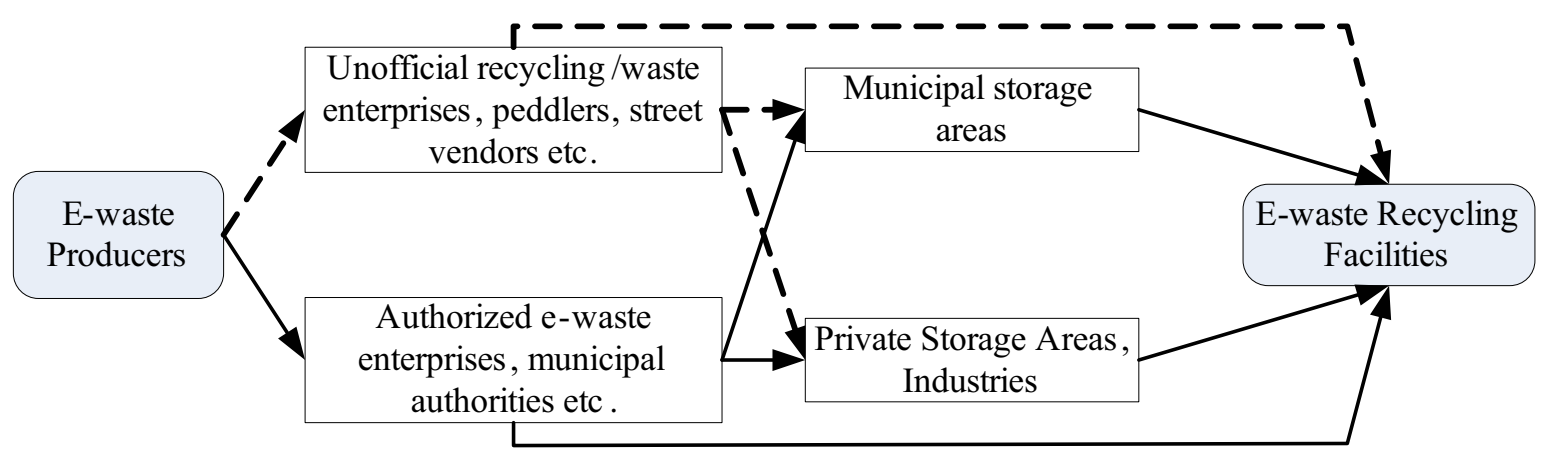

$\longrightarrow$ Monitored (authorized) e-waste stream

Figure 3. Procedures flow chart of the operating e-waste management system in Greece.

prevention of environmental pollution, for the exploitation of resources and the reduction of landfill use. The legislation developed by the European Parliament is based on three axes, the prevention, recycling and re-use of e-waste, so that the amount of the waste electrical and electronic equipment available is reduced [9]. The above are elaborated in two relative Directives:

1. Directive 2002/95/EC (RoHS-Restriction of Hazardous Substances) restricts the use of hazardous substances introducing the requirement for change of substances causing the main environmental problems during the emplacement and recycling of the waste electrical and electronic equipment. According to this directive, the most effective way to ensure the substantial reduction of health and environmental hazards relating to hazardous substances is their replacement with other, safer substances. The prohibition of use of hazardous substances is most likely to increase the possibilities and the financial profit from recycling electrical and electronic equipment.

2. Directive 2002/96/EC on waste electrical and electronic equipment has been developed particularly to assist in reducing the waste electrical and electronic equipment available in the landfills and encourage the more efficient use of resources through recycling and re-use. The specific directive measures for collection, management, recovery and recycling of all electrical and electronic products and focuses on the Extended Producer Responsibility (EPR). Its main points are:

- The study and production of electronic equipment should facilitate the disassembly and recovery for posterior use and recycling of e-waste.

- The e-waste should be collected separately from other forms of waste and their collection should not burden households.

- The target price to integrate in the management system is $4 \mathrm{~kg} /$ year/resident.

- By the end of 2006, producers should be able to recover and reuse a certain target percentage for each of the 10 categories of the Directive ranging between $50-80 \%$.

- Producers are responsible for financing e-waste collection and management.

\subsection{Switzerland}

Switzerland was the first country in the world where an official e-waste management system was established and operated [10]. The legislation regarding e-waste management was introduced for the first time in 1998 through ORDEA law (Ordinance on "The Return, the Taking Back and the Disposal of Electrical and Electronic Appliances") [5, 28]. Two different e-waste recycling systems are active in the country. One is run by SWICO Recycling Guarantee (The Swiss Association for Information, Communication and Organizational Technology) and manages the "brown" electronic equipment (e.g. computers, televisions, radios, etc.), while the other is run by S.EN.S (Stiftung Entsorgung Schweiz System) and manages the "white" electrical equipment (e.g. washing machines, refrigerators, ovens, etc.) [10].

More specifically, consumers return the e-waste in a more convenient way, either through specified collection points, of retail companies or transporting the waste straight to the recycling spots. The materials are transported from the collection points to the disassembly facilities, in order to disassemble and disinfect e-waste, by removing the most toxic factors. In the recycling facilities, e-waste pass through an even more detailed disassembly, shredding and sorting, resulting mostly to the collection of plastic, glass, steel, aluminum and copper. Most of the recycled materials are then sent to refineries or foundries for the final material recovery. The remaining materials that cannot be recovered are led into incinerators for energy recovery and a small quantity, usually smaller than $2 \%$, ends up to landfills.

In the Swiss system, producers are fully responsible for the application and operation of the management system and the entire system is financed through a special recycling charge included in the product's price [5]. Retailers, importers and manufacturers are obliged to take back their products free of charge and manage them in an "environmentally tolerable way" [28]. Approximately $75 \mathrm{Kt}$ of electrical and electronic equipment have been collected, classified, disassembled and then processed in Switzerland in 2004, as a result of the effort of these systems [9], while approximately $68 \mathrm{Kt}$ were collected in 2003 [10]. 


\subsection{Japan}

In the Japanese e-waste management system the withdrawal is not free of charge, but consumers pay an amount of money when they return used electronic products to the traders. Japan has established a withdrawal system for four types of e-waste (air conditioners, televisions, refrigerators and washing machines) since 1998. The law specifies target rates and imposes strict penalties for non-compliance [5]. Until 2004 there were $41 \mathrm{e}$-waste recycling facilities in Japan, partially financed by the ministries, municipalities or Japanese companies producing electronic products. Producers implement in their business strategy the e-waste management and have their own facilities or collaborate with other producers to create and operate such facilities. E-waste coming from residencies are collected when these products are not used anymore or when consumers buy new ones. The collected waste is transported to the intermediate 380 e-waste collection points and eventually to the facilities through a distribution system [29]. A basic characteristic of the Japanese system is the use of the primary disassembly procedure of big parts initially with a more accurate and brief process so that they handle the residues in a more proper way. Therefore, the Japanese companies of electronic equipment were the first ones to evolve welding without insulation and the electrical panel board connections without bromide compounds in relation to the European guidelines of the Directive RoHS, while they constantly aim at the designing of lighter products, cheaper and easier to be recycled. They plan the disassembly by reducing the number of the plastic resins in their products and reuse their parts [28].

Equivalent legislation is in force also for the collection and recycling of used electronic computers since 2003. The legal framework provides for two different categories for the used electronic computers. For those bought before October 2001, recycling is financed with $20-30 €$, while for those bought after October 2001, the recycling costs are included in the price of the product as an additional recycling tax. This legislation also directs on order the manufacturers to recover their corresponding products after they have been used by their last owners. This system is an example for the individual responsibility of producers, from the moment they have the natural and financial responsibility for their products recycling. Nevertheless, it should be noted that the e-waste recycling system success in Japan is based on social responsibility, environmental sensitivity and general discipline of Japanese people vis-à-vis regulations.

\section{Conclusions}

Electronic equipment and therefore e-waste are everywhere in our society. They are characterized by a complex chemical composition and difficulty in quantifying their flows at a local and international level. The pollution caused by their irregular management substantially degraded the environment mostly in poorer countries, receiving them for recycling and recovery of their valuable metals. As for the consequences on ecosystems, human health and environmental restoration of areas burdened by certain polluters generated by e-waste (e.g. Li and $\mathrm{Sb}$ ), there are no sufficiently documented scientific studies. Motivated by the minimization of environmental effects caused by the generated e-waste, many technological changes have been effectuated. The following are indicated:

- The replacement of CRT screens with LCD screens $(\mathrm{Pb}$ elimination but $\mathrm{Hg}$ introduction),

- The introduction of optical fibres ( $\mathrm{Cu}$ elimination from the cablings, but F, Pb, Y and $\mathrm{Zr}$ introduction),

- The introduction of rechargeable batteries $(\mathrm{Ni}, \mathrm{Cd}$ reduction, but Li increase), etc.

Non-governmental organizations and citizens movements press for the elimination of hazardous substances in electronic appliances, resulting to manufacturers competing for a more "green" profile. Some indicative results of the above pressures are:

- The production of "halogen-free" appliances, not contributing to the production of PCBs and dioxins (but their production is more expensive environmentally),

- The replacement of bromide combustion retarders with more environment-friendly ones based on phosphorus, and

- The introduction of legislative restrictions $(\mathrm{Pb}, \mathrm{Hg}, \mathrm{Cr}$, PBBs and PBDE up to $1000 \mathrm{mg} / \mathrm{kg}$, Directive RoHS - Restriction on Hazardous Substances).

Summarizing the above, e-waste separation from the rest of solid waste and their recycling for the recovery of valuable raw materials and basic metals is essential. The management system has to be rationally designed so that the environmental benefits from the collection, transportation, management and the financial benefits from the recovery are not set-off by the required resources and energy consumptions for the system operation.

\section{References}

1. A. Terazono, S. Murakami, N. Abe, B. Inanc, Y. Moriguchi and S. Sakai, Current status and research on e-waste issues in Asia, J Mater Cycles Waste Manage. 8, pp. 1-12 (2006).

2. M. Cobbing, Toxic Tech: Not in Our Backyard. Uncovering the Hidden Flows of e-waste. Report from Greenpeace International. http://www. greenpeace.org/raw/content/belgium/fr/press/reports/toxic-tech.pdf, Amsterdam, (2008).

3. UNEP, Call for Global Action on E-waste, United Nations Environment Programme (2006).

4. OECD, OECD Environmental Outlook to 2030. Organisation for Economic Cooperation and Development http://213.253.134.43/oecd/pdfs/
browseit/9708011E.PDF, (2008).

5. R. Widmer, H. Oswald-Krapf, D. Sinha-Khetriwal, M. Schnellmann and H. Boni, Global perspectives on e-waste, Environ Impact Assess Rev. 25, pp. 436-458 (2005)

6. K. Betts, Producing usable materials from e-waste, Environ Sci Technol. 42, pp. 6782-6783 (2008).

7. B. Robinson, E-waste: An assessment of global production and environmental impacts, Science of the Total Environment, 408, pp. 183-191 (2009).

8. J. H. Li, S. Gao, H. B. Duan and L. L. Liu, Recovery of valuable materials from waste liquid crystal display panel. Waste Manag. 29, pp. 2033-9 
(2009)

9. R. Hischier, P. Wäger and J. Gauglhofer, Does WEEE Recycling make sense from an environmental perspective? The environmental impacts of the Swiss take-back and recycling systems for waste electrical and electronic equipment (WEEE), Environ Impact Assess Rev. 25, pp. 525-539 (2005).

10. D. Sinha-Khetriwal, P. Kraeuchi and M. Schwaninger, A comparison of electronic waste recycling in Switzerland and in India, Environ Impact Assess Rev. 25, pp. $492-504$ (2005).

11. M. Goosey, End-of-life electronics legislation-an industry perspective, Circuit World, 30 (2), pp. 41-45 (2004).

12. J. Huisman and F. Magalini, Where are WEEE now?, Lessons from WEEE: Will EPR work for the US?, Proceedings of the 2007 IEEE International Symposium on Electronics \& the Environment, Conference Record, pp. 149-154 (2007).

13. X. B. Liu, M. Tanaka and Y. Matsui, Generation amount prediction and material flow analysis of electronic waste: a case study in Beijing, China Waste Manag Res. 24, pp. 434-445 (2006).

14. B. K. Gullett, W. P. Linak, A. Touati, S. J. Wasson, S. Gatica and C. J. King, Characterization of air emissions and residual ash from open burning of electronic wastes during simulated rudimentary recycling operations, J Mater Cycl Waste Manag. 9, pp. 69-79 (2007).

15. e-waste, ewasteguide.info - a knowledge base for the sustainable recycling of e-Waste, Hazardous Substances in e-waste, http://ewasteguide. info/hazardous_substances, (2010).

16. L. S. Morf, J. Tremp, R. Gloor, F. Schuppisser, M. Stengele and R. Taverna, Metals, non-metals and PCB in electrical and electronic waste - actual levels in Switzerland. Waste Manag. 27, 1306-16 (2007).

17. M. Bertram, T. E. Graedel, H. Rechberger and S. Spatari, The contemporary European copper cycle: waste management subsystem, Ecol Econ. 42, pp. 43-57 (2002).

18. W. J. Deng, J. S. Zheng, X. H. Bi, J. M. Fu and M. H. Wong, Distribution of PBDEs in air particles from an electronic waste recycling site compared with Guangzhou and Hong Kong, South China, Environ Int. 33, pp. 1063 1069 (2007).

19. C. Scheutz, H. Mosbaek and P. Kjeldsen, Attenuation of methane and volatile organic compounds in landfill soil covers, J Environ Qual. 33, pp. 61-71 (2004)

20. J. Ladou and S. Lovegrove, Export of electronics equipment waste, Int J Occup Environ Health. 14, pp. 1-10 (2008).

21. C. W. Schmidt, Unfair trade - E-waste in Africa, Environ Health Perspect. 114, pp. A232- A235 (2006).

22. E. Spalvins, B. Dubey and T. Townsend, Impact of electronic waste disposal on lead concentrations in landfill leachate, Environ Sci Technol. 42, pp. 7452-7458 (2008).

23. R. Dagan, B. Dubey, G. Bitton and T. Townsend, Aquatic toxicity of leachates generated from electronic devices, Arch Environ Contam Toxicol. 53, pp. 168-173 (2007).

24. X. J. Niu and Y. D. Li, Treatment of waste printed wire boards in electronic waste for safe disposal, J Hazard Mater. 145, pp. 410-416 (2007).

25. H. Aizawa, H. Yoshida and S. I. Sakai, Current results and future perspectives for Japanese recycling of home electrical appliances, Res Conserv Recycl. 52, pp. 1399-1410 (2008).

26. Y. Barba-Gutierrez, B. Adenso-Diaz and M. Hopp, An analysis of some environmental consequences of European electrical and electronic waste regulation, Res Conserv Recycl. 52, pp. 481-495 (2008).

27. www.electrocycle.gr

28. B. K. Fishbein, End-of-life management of electronics abroad, Waste in the wireless world: the challenge of cell phones, INFORM Inc., New York, http://www.informinc.org. (2002).

29. J. Li, X. Wen, T. Liu and S. Honda, Policies, management, technologies and facilities for the treatment of electrical and electronic wastes in China. The China-Netherlands Seminar on Recycling of electronic Wastes, Beijing. http://www.bcrc.cn/en/Backup/Meetings/China-Netherland/10.pdf (2004). 